IZA DP No. 4662

Outsourcing, Public Input Provision and Policy Cooperation

Thomas Aronsson

Erkki Koskela

December 2009 


\title{
Outsourcing, Public Input Provision and Policy Cooperation
}

\author{
Thomas Aronsson \\ Umeå University \\ Erkki Koskela \\ University of Helsinki \\ and IZA
}

\section{Discussion Paper No. 4662 \\ December 2009}

\author{
IZA \\ P.O. Box 7240 \\ 53072 Bonn \\ Germany \\ Phone: +49-228-3894-0 \\ Fax: +49-228-3894-180 \\ E-mail: iza@iza.org
}

\begin{abstract}
Any opinions expressed here are those of the author(s) and not those of IZA. Research published in this series may include views on policy, but the institute itself takes no institutional policy positions.

The Institute for the Study of Labor (IZA) in Bonn is a local and virtual international research center and a place of communication between science, politics and business. IZA is an independent nonprofit organization supported by Deutsche Post Foundation. The center is associated with the University of Bonn and offers a stimulating research environment through its international network, workshops and conferences, data service, project support, research visits and doctoral program. IZA engages in (i) original and internationally competitive research in all fields of labor economics, (ii) development of policy concepts, and (iii) dissemination of research results and concepts to the interested public.
\end{abstract}

IZA Discussion Papers often represent preliminary work and are circulated to encourage discussion. Citation of such a paper should account for its provisional character. A revised version may be available directly from the author. 
IZA Discussion Paper No. 4662

December 2009

\section{ABSTRACT}

\section{Outsourcing, Public Input Provision and Policy Cooperation ${ }^{*}$}

This paper concerns public input provision as an instrument for redistribution under international outsourcing by using a model-economy comprising two countries, North and South, where firms in the North may outsource part of their low-skilled labor intensive production to the South. We consider two interrelated issues: (i) the incentives for each country to modify the provision of public input goods in response to international outsourcing, and (ii) whether international outsourcing justifies policy cooperation. If the public input good is substitutable for (complementary with) outsourcing in terms of the production function faced by northern firms, then outsourcing contributes to increase (decrease) the public input provision in the North. For the South, the optimal policy response depends on the level of outsourcing. We also show how policy cooperation with respect to public input provision can be designed to increase the overall social welfare.

JEL Classification: H21, H25, J31, J62

Keywords: $\quad$ outsourcing, redistribution, public input goods, asymmetric information

Corresponding author:

Erkki Koskela

Department of Economics

University of Helsinki

P.O. Box 17 (Arkadiankatu 17)

00014 Helsinki

Finland

E-mail: erkki.koskela@helsinki.fi

\footnotetext{
* The authors would like to thank Tomas Sjögren for helpful comments and suggestions. Aronsson would also like to thank The Bank of Sweden Tercentenary Foundation, The Swedish Council for Working Life and Social Research and The National Tax Board for research grants. Koskela thanks The Academy of Finland (grant No. 1217622) for financial support and Department of Economics, Umeå University, for good hospitality.
} 


\section{Introduction}

Along with the process of international integration, firms in industrialized economies have found it increasingly attractive to outsource the production of labor intensive components. One important motivation for this behavior is to exploit cost advantages by locating this production in countries with lower wages. There is now a substantial body of empirical evidence showing that international outsourcing leads to more wage-inequality by increasing the skill-premium in countries that outsource production abroad. ${ }^{1}$ This suggests that the appearance of international outsourcing provides new challenges for redistributive public policy in such economies, as it may create additional demand for redistribution. The need for understanding the implications of international outsourcing for redistribution policies is further emphasized by the fact that outsourcing also influences the income prospects of the residents, as well as the scope for redistribution policy, in the (low-wage) "host-countries" that gain employment opportunities for their own domestic labor force. ${ }^{2}$ The present paper examines the role of public input provision as an instrument for redistribution in the presence of outsourcing. Our analysis is based on a model-economy comprising two countries, North and South, where each country is characterized by two ability-types, and where the firms in the North may outsource part of their low-skilled labor intensive production to the South. This model will be used to address two interrelated research questions: (i) whether, and how, each such country modifies its provision of public input goods in response to outsourcing in the absence of any policy cooperation among the countries, and (ii) whether the appearance of international outsourcing justifies policy cooperation with respect to public input provision.

Why is it interesting to analyze public input goods in this particular context? First, as public input provision can be designed to enhance the productivity of domestic labor, it

$1 \quad$ See, e.g., Feenstra and Hanson (1999, 2003), Hijzen et al. (2005), Hsieh and Woo (2005), Egger and Egger, (2006), Hijzen (2007), Riley and Young (2007), Geishecker and Görg (2008) and Munch and Skaksen (2009).

2 Goldberg and Pavcnik (2007) survey the empirical literature on the effects of globalization on inequality in developing countries. Their discussion suggests that globalization has meant increased inequality. However, the concept of "increased globalization" reflects a number of phenomena such as, e.g., trade liberalization, increased capital mobility and increased international outsourcing, meaning that the effects of globalization on inequality do not only reflect effects of outsourcing. At present, there is not much evidence regarding the effects of outsourcing. 
may be used as an indirect instrument to influence the level of outsourcing. ${ }^{3}$ As the level of outsourcing directly affects the wage distribution both in the North and the South, this argument suggests that public input provision constitutes a means for each national government to avoid undesirable distribution effects, or strengthen desirable distribution effects, of international outsourcing. Furthermore, as each national government may disregard the effects of outsourcing on the wage distribution in the other country, it follows that the level of public input provision decided upon at the national level is not necessarily optimal for society as a whole. Second, public input goods constitute natural supplements to redistributive income taxation, which (together with social insurance) is the type of instrument that the existing - yet very scarce - literature dealing with optimal policy responses to outsourcing has typically focused on. ${ }^{4}$ It is, therefore, interesting to examine the remaining role for public input provision when the income tax is optimally chosen. This is precisely what we will do below.

Our study is closely related to a paper by Aronsson and Koskela (2009c), which deals with optimal nonlinear labor and capital income taxation in a two-country overlapping generations economy where the firms in one of the countries (the North) may outsource part of the low-skilled labor intensive production to the other (the South). Their results show that the government in the North responds to international outsourcing by implementing a more progressive labor income tax (i.e. lower marginal taxation of lowability labor and higher marginal taxation of high-ability labor) and by implementing higher marginal capital income taxation of all individuals. The intuition is that this policy response leads to less outsourcing which, in turn, contributes to a more equal wage distribution. In the South, on the other hand, the government has an incentive to stimulate outsourcing, as increased outsourcing leads to more wage-equality in the southern economy. The optimal tax response to outsourcing by the southern government is, nevertheless, ambiguous in general as it serves to balance two counteracting incentives: a desire to increase the level of outsourcing and an incentive to increase the budgetary gain of outsourcing via a higher wage rate to low-ability labor. Their results also show how tax

3 There is a large literature dealing with different aspects of public input provision in model-economies without outsourcing. See, e.g., Hillman (1978), McMillan (1979), Feehan (1989), Feehan and Matsumoto (2000), Matsumoto (1998, 2001, 2004) and Aronsson and Wehke (2008).

See, e.g., Aronsson and Koskela (2009a) and Keuschnigg and Ribi (2009). These studies focus on policy responses by governments in high-wage economies, i.e. countries that outsource part of their labor intensive production, while disregarding the policy implications for the (low-wage) host-countries that receive foreign production structure. 
policy cooperation can be designed to increase the overall social welfare. A basic insight here is that the South would benefit from reduced labor tax progression and/or lower marginal capital income tax rates in the North, and that the North under reasonable assumptions may benefit from the same tax policy adjustment in the South.

There are only a few earlier studies dealing with the optimal provision of public input goods under international outsourcing. Egger and Falkinger (2006) consider a twocountry economy where final goods producers outsource intermediate goods production and focus on the location choices among intermediate goods producers. In their study, public infrastructure investments constitute means of increasing a country's attractiveness for intermediate goods producers. The results show that increased public infrastructure investments have a positive effect on the number of domestic intermediate goods producers, meaning that international outsourcing declines. Furthermore, by attracting firms, each national government imposes a negative externality on the other (which loses firms), suggesting that an uncoordinated equilibrium leads to overprovision of public infrastructure relative to the first best resource allocation. ${ }^{5}$ Aronsson and Koskela (2009b) consider an economy with a single jurisdiction, where the firms outsource production to other countries (i.e. a partial model for the "North”), and where part of the low-skilled labor force is subject to involuntary unemployment. In their framework, the policy problem facing the government is represented by an optimal income tax model extended by a factor-augmenting public input good. The results show that if the government lacks a direct tax instrument for influencing the amount of resources spent on outsourcing by domestic firms, it will respond to international outsourcing by increased provision of the public input good.

The present paper uses a two-country model similar to that in Aronsson and Koskela (2009c) - yet based on a static formulation - to analyze public input provision. In each country, the policy-problem faced by the government is based on an extension of the twotype optimal income tax model originally developed by Stern (1982) and Stiglitz (1982), where individual ability is private information. The policy instruments are a nonlinear labor income tax and a public input good that directly affects the productivity of the two

5 See also the related study by Martin and Rogers (1995), which concerns the effects of public infrastructure on industrial location. However, these authors do not address the optimal choice of public infrastructure. 
types of labor. ${ }^{6}$ Our focus will be on the incentives underlying public input provision, and we start by characterizing the provision made by each national government in a noncooperative Nash equilibrium, in which each national government treats the policyvariables of the other country as exogenous. As the level of outsourcing directly affects the wage-distribution in both countries in our model, while each national government may influence the level of outsourcing via public input provision, it follows that the noncooperative Nash equilibrium is suboptimal from the perspective of society as a whole. As a consequence, we also examine how policy cooperation with respect to the provision of public input goods can be used to increase the social welfare.

To our knowledge, there are no earlier studies dealing with the redistributive role of public input goods in a multi-country framework, in which there is a distinction between countries that outsource production abroad and countries that receive employment opportunities for their own residents via outsourcing. Therefore, the main contribution of the present paper is to fill this gap. As such, our study also provides a natural complement to the paper by Aronsson and Koskela (2009c), which uses a similar model to analyze the optimal tax responses to international outsourcing. The outline of the paper is as follows. Section 2 describes the model and characterizes the outcome of private optimization. In Section 3, we describe the decision-problem facing each national government and analyze public input provision in a noncooperative Nash equilibrium. The welfare effects of policy cooperation are addressed in Section 4. The results are summarized and discussed in Section 5 .

\section{The Model}

Consider an economy comprising two countries, which will be referred to as North $(n)$ and South (s). We assume that North outsources part of its production to South, which will be explained more thoroughly below. We start by describing the decision-problems facing the consumers and firms, and then continue with the outcome of private optimization.

\subsection{Consumers}

$6 \quad$ As our study is based on a static model, it does not contain capital formation and capital income taxation. To simplify the analysis, we also abstract from tax competition for mobile capital. For a survey on theories of tax competition, see Wilson (1999). 
In each country, there are two types of immobile ${ }^{7}$ consumers; a low-ability type (denoted by superindex 1) and a high-ability type (denoted by superindex 2). The distinction between ability-types refers to productivity, which is interpreted to mean that the highability type faces a higher before tax wage rate than the low-ability type. As the number of individuals of each ability-type is not important for the qualitative results derived below, it will be normalized to one in what follows.

The utility function facing ability-type $i$ in country $j$ is given by

$$
u_{j}^{i}=u\left(c_{j}^{i}, z_{j}^{i}\right)
$$

where $c$ denotes private consumption and $z$ leisure. Leisure is, in turn, defined as a time endowment, $H$, less the hours of work, $l$. The utility function is increasing in each argument and strictly quasi-concave. Let $w$ denote the before-tax hourly wage rate. The individual budget constraint can then be written as

$$
w_{j}^{i} l_{j}^{i}-T_{j}\left(w_{j}^{i} l_{j}^{i}\right)=c_{j}^{i}
$$

in which $T_{j}\left(w_{j}^{i} l_{j}^{i}\right)$ represent the income tax payment. Note that the tax function may vary between the countries. The consumer price is normalized to one.

The first order condition for work hours becomes

$$
u_{j, c}^{i} w_{j}^{i}\left(1-T_{j}^{\prime}\left(w_{j}^{i} l_{j}^{i}\right)\right)-u_{j, z}^{i}=0
$$

where we have used the short notations $u_{j, c}^{i}=\partial u_{j}^{i} / \partial c_{j}^{i}$ and $u_{j, z}^{i}=\partial u_{j}^{i} / \partial z_{j}^{i}$, while $T_{j}^{\prime}\left(w_{j}^{i} l_{j}^{i}\right)$ is the marginal income tax rate.

As long as real world labor mobility is costly (e.g., via an "attachment-to-home" component in the utility function), this assumption is not particularly restrictive for the analysis to be carried out below. Even if we were to add imperfect labor mobility to the model, the policy incentives associated with outsourcing derived below would still be present. With perfect (i.e. costless) labor mobility, on the other hand, things change dramatically: in that case, the factor prices would become equalized among countries, meaning that the incentives for outsourcing would vanish. 


\subsection{Production}

Turning to the production side, we assume that each country is characterized by identical competitive firms producing a homogenous good using labor of both ability-types. There is also a public input good, which works to increase the productivity of both types of domestic labor. One of the countries, referred to as North $(j=n)$, locates part of its lowskilled labor intensive production in the other country, referred to as South $(j=s)$. In particular, this means that firms in the North partly use low-skilled labor from the South in their production and have to pay the southern low-skilled wage rate for their services. To shorten the notation, we normalize the number of firms in each country to one.

Production in the North

The production function of the representative firm is written as

$$
F_{n}=F_{n}\left(a_{n}^{1}\left(g_{n}\right) l_{n}^{1}+\delta l_{n s}^{1}, a_{n}^{2}\left(g_{n}\right) l_{n}^{2}\right)
$$

where $g$ denotes the public input good, and $l_{n s}^{1}$ the low-skilled labor (measured in work hours) by residents in the South that are used by northern firms. The function $a_{j}^{i}\left(g_{j}\right)$ is increasing and strictly concave in $g_{j}$. The parameter $\delta$ captures the idea that foreign labor may not be a perfect substitute for domestic labor; if foreign labor is a less that perfect substitute for domestic labor, we have $\delta \in(0,1)$.

We assume that the production function is increasing and strictly concave in each of its two "basic arguments", i.e.

$$
\begin{aligned}
& \frac{\partial F_{n}(\cdot)}{\partial\left(a_{n}^{1}\left(g_{n}\right) l_{n}^{1}+\delta l_{n s}^{1}\right)}=F_{n, 1}>0, \frac{\partial F_{n}(\cdot)}{\partial\left(a_{n}^{2}\left(g_{n}\right) l_{n}^{2}\right)}=F_{n, 2}>0 \text { and } \\
& \frac{\partial^{2} F_{n}(\cdot)}{\left(\partial a_{n}^{1}\left(g_{n}\right) l_{n}^{1}+\delta l_{n s}^{1}\right)^{2}}=F_{n, 11}<0, \frac{\partial^{2} F_{n}(\cdot)}{\left(\partial a_{n}^{2}\left(g_{n}\right) l_{n}^{2}\right)^{2}}=F_{n, 22}<0,
\end{aligned}
$$

and that it is characterized by constant returns to scale in the basic arguments. In addition, the second order cross-derivative is positive, i.e. $F_{n, 12}>0$, meaning that the two private 
production factors are technical complements. These properties imply that outsourced labor, $l_{n s}^{1}$, is substitutable for domestic low-skilled labor, $l_{n}^{1}$, and complementary with domestic high-skilled labor, $l_{n}^{2} \cdot 8$ As a consequence, increased outsourcing leads to increased domestic wage-inequality, which is in line with empirical evidence (see footnote 1).

There is also a capacity aspect of outsourcing, as the firm needs to build costly capacity abroad. We assume that while some activities are easy to outsource, other activities are more costly. Therefore, the marginal cost of outsourcing increases in the scope of activities to outsource, so that there is a capacity cost of outsourcing, $\psi\left(l_{n s}^{1}\right)$, which is increasing and convex, i.e. $\psi^{\prime}\left(l_{n s}^{1}\right)>0, \psi^{\prime \prime}\left(l_{n s}^{1}\right) \geq 0$. This formulation captures the idea that outsourcing may necessitate costly investments into the establishment of network of suppliers in relevant host-countries.

The objective function facing the firm can be written as

$$
\pi_{n}=F_{n}\left(a_{n}^{1}\left(g_{n}\right) l_{n}^{1}+\delta l_{n s}^{1}, a_{n}^{2}\left(g_{n}\right) l_{n}^{2}\right)-w_{n}^{1} l_{n}^{1}-w_{n}^{2} l_{n}^{2}-\psi\left(l_{n s}^{1}\right)-w_{s}^{1} l_{n s}^{1} .
$$

As before, $w_{n}^{1}$ and $w_{n}^{2}$ denote the before-tax wage rates paid to low-skilled and highskilled labor, respectively, in the North. The variable $w_{s}^{1}$ denotes the before-tax wage rate paid to low-skilled labor the South, i.e. the wage rate that northern firms must pay to outsourced labor. The first order conditions are given by

$$
\begin{aligned}
& a_{n}^{1}\left(g_{n}\right) F_{n, 1}\left(a_{n}^{1}\left(g_{n}\right) l_{n}^{1}+\delta l_{n s}^{1}, a_{n}^{2}\left(g_{n}\right) l_{n}^{2}\right)-w_{n}^{1}=0 \\
& a_{n}^{2}\left(g_{n}\right) F_{n, 2}\left(a_{n}^{1}\left(g_{n}\right) l_{n}^{1}+\delta l_{n s}^{1}, a_{n}^{2}\left(g_{n}\right) l_{n}^{2}\right)-w_{n}^{2}=0 \\
& \delta F_{n, 1}\left(a_{n}^{1}\left(g_{n}\right) l_{n}^{1}+\delta l_{n s}^{1}, a_{n}^{2}\left(g_{n}\right) l_{n}^{2}\right)-\psi^{\prime}\left(l_{n s}^{1}\right)-w_{s}^{1}=0 .
\end{aligned}
$$

8 Ethier (2005) uses a production function with similar properties (yet based on a specific functional form assumption) to study the effects of globalization on the skill-premium. See also Koskela and Stenbacka (in press), who examine the effects of outsourcing for trade-union wage formation by using a production function where outsourcing is substitutable for low-skilled labor and complementary with high-skilled labor. 
Note that equation (8) implicitly defines the amount of outsourced labor as a function of the labor supplied by the northern low-ability and high-ability type, respectively, the northern public input good and the before-tax wage rate paid to low-ability labor in the South, i.e.

$$
l_{n s}^{1}=l_{n s}^{1}\left(-l_{n}^{1}, l_{n}^{2}, \stackrel{?}{g_{n}},-w_{s}^{1}\right)
$$

In equation (9), the sign-indicator above each argument shows the qualitative comparative statics effect. The ambiguity with respect to the effect of the public input good arises because public input provision directly increases the productivities of both types of domestic labor which, in turn, correlate with outsourcing in opposite directions.

To be more specific, one can show that the partial effect of the public input good in equation (9) is negative, if $a_{n}^{1^{\prime}}\left(g_{n}\right) l_{n}^{1}\left|F_{n, 11}\right|>a_{n}^{2^{\prime}}\left(g_{n}\right) l_{n}^{2}\left|F_{n, 12}\right|$, where $a_{n}^{i^{\prime}}\left(g_{n}\right)=\partial a_{n}^{i}\left(g_{n}\right) / \partial g_{n}$. This condition is interpretable to mean that an increase in $g_{n}$ reduces the marginal product of outsourced labor. The greater $a_{n}^{1^{\prime}}\left(g_{n}\right)$ relative to $a_{n}^{2^{\prime}}\left(g_{n}\right)$, or the weaker the degree of complementary between the two types of domestic labor (i.e. the smaller $F_{n, 12}$ ), the more likely it is that this condition is fulfilled. In this case, we refer to the public input good as being substitutable for outsourcing. Conversely, the partial effect of increased public input provision in equation (9) is positive, if the inequality goes in the opposite direction, in which case an increase in the public input good contributes to increase the marginal product of outsourced labor. The underlying mechanism is either that an increase in the public input good has a relatively large effect on the measure of "effective high-ability labor", $a_{n}^{2}\left(g_{n}\right) l_{n}^{2}$, or that the degree of complementary (measured by $F_{n, 12}$ ) is relatively large. In this case, therefore, we refer to the public input good as being complementary with outsourcing.

Production in the South 
Let $l_{s}^{1}=l_{d s}^{1}+l_{n s}^{1}$ be the total labor supply by the low-ability type in the South, where $l_{d s}^{1}$ is the low-skilled labor supplied to domestic production in the southern economy. The production function in the South is written as

$$
F_{s}=F_{s}\left(a_{s}^{1}\left(g_{s}\right)\left(l_{s}^{1}-l_{n s}^{1}\right), a_{s}^{2}\left(g_{s}\right) l_{s}^{2}\right)
$$

Equation (10) is assumed to have the same general properties as the production function in the North, i.e. the production function is characterized by a positive and diminishing marginal product with respect to each basic argument $\left(F_{s, 1}>0, F_{s, 2}>0, F_{s, 11}<0\right.$ and $\left.F_{s, 22}<0\right)$, constant returns to scale, and technical complementarity $\left(F_{s, 12}>0\right) .{ }^{9}$ The objective function of the representative firm is given by

$$
\pi_{s}=F_{s}\left(a_{s}^{1}\left(g_{s}\right)\left(l_{s}^{1}-l_{n s}^{1}\right), a_{s}^{2}\left(g_{s}\right) l_{s}^{2}\right)-w_{s}^{1}\left(l_{s}^{1}-l_{s n}^{1}\right)-w_{s}^{2} l_{s}^{2} .
$$

The first order conditions become

$$
\begin{aligned}
& a_{s}^{1}\left(g_{s}\right) F_{s, 1}\left(a_{s}^{1}\left(g_{s}\right)\left(l_{s}^{1}-l_{n s}^{1}\right), a_{s}^{2}\left(g_{s}\right) l_{s}^{2}\right)-w_{s}^{1}=0 \\
& a_{s}^{2}\left(g_{s}\right) F_{s, 2}\left(a_{s}^{1}\left(g_{s}\right)\left(l_{s}^{1}-l_{n s}^{1}\right), a_{s}^{2}\left(g_{s}\right) l_{s}^{2}\right)-w_{s}^{2}=0 .
\end{aligned}
$$

Equations (9) and (11) implicitly define the low-skilled wage rate in the South as a function of work hours and provision of public input goods in both countries, i.e.

$$
w_{s}^{1}=w_{s}^{1}\left(\overline{l_{s}^{1}}, l_{s}^{2}, \stackrel{?}{g_{s}}, l_{n}^{1}, l_{n}^{2}, \stackrel{?}{g_{n}}\right) \text {. }
$$

The intuition behind equation (13) is straight forward. Starting with the variables accruing to the South, the influence of $l_{s}^{1}$ reflects a labor supply effect on the wage rate (due to

$9 \quad$ Note that our model is based on the assumption that the skilled-labor concept does not differ between the North and South. Goldberg and Pavcnik (2007) argue that developed and developing countries may differ in the sense that low-skilled labor intensive jobs outsourced from developed countries appear to be skilled-labor intensive relative to the domestic production from the perspective of developing countries. Although we abstract from possible differences in the skilled-labor concept here, this idea is clearly worthwhile to address in future research. 
concavity of the production function), whereas the qualitative effect of $l_{s}^{2}$ is due to complementary between the two types of labor. The effects of labor hours by northern residents, $l_{n}^{1}$ and $l_{n}^{2}$, follow from the properties of the production function in combination with equation (9) above.

The ambiguity with respect to the effect of the public input good of the North is analogous to the ambiguous effect that this variable has in terms of outsourcing in equation (9). If the public input good of the North is substitutable for outsourcing in the sense described in the interpretation of equation (9) above, then equation (13) implies $\partial w_{s}^{1} / \partial g_{n}<0$. The intuition is, of course, that reduced outsourcing means increased domestic labor supply by the low-ability type in the South and, therefore, a lower wage rate. By analogy, if the public input good of the North is complementary with outsourcing, then $\partial w_{s}^{1} / \partial g_{n}>0$.

Turning to the effect of the public input good of the South, $g_{s}$, in equation (13), the ambiguous effect is due to an indirect relationship between $g_{s}$ and the marginal product of southern low-ability labor, which may counteract the direct positive effect of $g_{s}$ on this marginal product. This is seen by differentiating equation (13) with respect to $w_{s}^{1}$ and $g_{s}$, which gives

$$
\frac{\partial w_{s}^{1}}{\partial g_{s}}=\frac{a_{s}^{1^{\prime}}\left(g_{s}\right) F_{s, 1}+a_{s}^{1}\left(g_{s}\right)\left[a_{s}^{1^{\prime}}\left(g_{s}\right) l_{d s}^{1} F_{s, 11}+a_{s}^{2^{\prime}}\left(g_{s}\right) l_{s}^{2} F_{s, 12}\right]}{\Omega}
$$

where $\Omega=1+\left[a_{s}^{1}\left(g_{s}\right)\right]^{2} F_{s, 11}\left[\partial l_{n s}^{1} / \partial w_{s}^{1}\right]>0$.

In equation (14), the expression within square brackets can be either positive or negative, as an increase in the public input good increases the effective labor input of both abilitytypes which, in turn, have indirect effects on the marginal product of low-ability labor. As our study attempts to capture the effects of a productivity-enhancing public input, we assume that this indirect effect is never strong enough to dominate the direct productivity 
increase of the public good summarized by the first term on the right hand side of equation (14). To be more specific, we add the following assumption;

A1: $a_{s}^{1^{\prime}}\left(g_{s}\right) F_{s, 1}>\left|a_{s}^{1}\left(g_{s}\right)\left[a_{s}^{1^{\prime}}\left(g_{s}\right) l_{d s}^{1} F_{s, 11}+a_{s}^{2^{\prime}}\left(g_{s}\right) l_{s}^{2} F_{s, 12}\right]\right| \leftrightarrow \frac{\partial w_{s}^{1}}{\partial g_{s}}>0$

\section{Public Provision in a Noncooperative Equilibrium}

In this section, we begin by a presentation of the decision-problem facing each national government. We will then turn to the public input provision in a noncooperative Nash equilibrium, where each national government treats the decision-variables facing the other national government as exogenous.

Each national government is assumed to face the following general social welfare function; ${ }^{10}$

$$
W_{j}=W_{j}\left(u_{j}^{1}, u_{j}^{2}\right)
$$

for $j=n, s$, which is increasing and concave in each argument.

The informational assumptions are conventional: the government observes the income of each individual, whereas ability is private information. This means that the government is not able to observe whether any given worker is a low-ability or high-ability type. By concentrating on the "normal” case, where redistribution means income transfers from the high-ability to the low-ability type, one would, therefore, like to prevent the highability type from mimicking the low-ability type in order to gain from the redistribution policy. The self-selection constraint that may bind then becomes

$$
u_{j}^{2}=u\left(c_{j}^{2}, z_{j}^{2}\right) \geq u\left(c_{j}^{1}, H-\phi_{j} l_{j}^{1}\right)=\hat{u}_{j}^{2}
$$

\footnotetext{
10 Another approach would be to assume that the government aims at maximizing the utility of one particular ability-type subject to a minimum utility restriction for the other. If we were to use this alternative approach, all qualitative results derived below would remain unchanged.
} 
where $\hat{u}_{j}^{2}$ denotes the utility of the mimicker and $\phi_{j}=w_{j}^{1} / w_{j}^{2}<1$ is the wage ratio, i.e. the relative wage rate. Note that the mimicker faces the same income and consumption point as the low-ability type and, therefore, pays as much tax as the low-ability type. However, as the mimicker is more productive than the low-ability type, he/she spends more time on leisure. We can interpret $\phi_{j} l_{j}^{1}$ as the labor that the mimicker needs to supply in order to reach the same income as the low-ability type. By using the first order conditions for the firm, the wage ratio can be written as

$$
\phi_{j}=\phi_{j}\left(l_{j}^{1}, l_{j}^{2}, g_{j}, l_{n s}^{1}\right)
$$

In particular, note that $\partial \phi_{n} / \partial l_{n s}^{1}<0$ and $\partial \phi_{s} / \partial l_{n s}^{1}>0$, suggesting that increased outsourcing leads to more wage-inequality in the North and less wage-inequality in the South.

We assume that any profit income is taxed away. By using the consumers' budget constraints and the objective function of the firm, we can write the national public budget constraint for the North and South, respectively, as follows;

$$
\begin{aligned}
& F_{n}\left(a_{n}^{1}\left(g_{n}\right) l_{n}^{1}+\delta l_{n s}^{1}, a_{n}^{2}\left(g_{n}\right) l_{n}^{2}\right)-c_{n}^{1}-c_{n}^{2}-g_{n}-\psi\left(l_{n s}^{1}\right)-w_{s}^{1} l_{n s}^{1} \\
& F_{s}\left(a_{s}^{1}\left(g_{s}\right)\left(l_{s}^{1}-l_{n s}^{1}\right), a_{s}^{2}\left(g_{s}\right) l_{s}^{2}\right)-c_{s}^{1}-c_{s}^{2}-g_{s}+w_{s}^{1} l_{n s}^{1} .
\end{aligned}
$$

Equation (18a) and (18b), respectively, implies that output is used for private and public consumption. The final term on the right hand side of each equation arises because outsourcing gives rise to an income effect, which differs between the countries. This is so because part of the income generated by the North accrues to residents in the South.

\subsection{Public Input Provision in the North}

Following the convention in earlier literature on the self-selection approach to optimal taxation, the decision-problem facing each national government is written as a direct decision-problem. Therefore, the government in the North behaves as if it chooses $l_{n}^{1}$, $c_{n}^{1}, l_{n}^{2}, c_{n}^{2}$ and $g_{n}$ to maximize the Lagrangean 


$$
L_{n}=W_{n}+\lambda_{n}\left[u_{n}^{2}-\hat{u}_{n}^{2}\right]+\gamma_{n}\left[F_{n}-c_{n}^{1}-c_{n}^{2}-g_{n}-\psi\left(l_{n s}^{1}\right)-w_{s}^{1} l_{n s}^{1}\right]
$$

The government in the North recognizes that $l_{n s}^{1}, w_{s}^{1}$ and $\phi_{n}$ are determined by equation (9), (13) and (17), respectively, and it treats the corresponding decision-variables of the southern government (i.e. $l_{s}^{1}, c_{s}^{1}, l_{s}^{2}, c_{s}^{2}$ and $g_{s}$ ) as exogenous. The first order conditions for $l_{n}^{1}, c_{n}^{1}, l_{n}^{2}$ and $c_{n}^{2}$ are presented in the Appendix.

We begin the analysis by deriving the welfare effect for the North of a small increase in the amount of outsourced labor, $l_{n s}^{1}$. By differentiating the Lagrangean with respect to $l_{n s}^{1}$ and using the first order conditions for the firm, we can derive

$$
\Lambda_{n}=\frac{\partial L_{n} / \partial l_{n s}^{1}}{\gamma_{n}}=\frac{\lambda_{n}}{\gamma_{n}} \hat{u}_{n, z}^{2} l_{n}^{1} \frac{\partial \phi_{n}}{\partial l_{n s}^{1}}<0 .
$$

Equation (19) means that increased outsourcing leads to more wage-inequality and, therefore, implies lower welfare in the North. Now, recall from equations (9) and (13) that the government in the North may influence $l_{n s}^{1}$ via $l_{n}^{1}$ and $l_{n}^{2}$, which it controls via the income tax, and by adjusting the public input good, $g_{n}$. We can derive the following effect on outsourcing from an increase in the public input good;

$$
\frac{d l_{n s}^{1}}{d g_{n}}=\frac{\partial l_{n s}^{1}}{\partial g_{n}}+\frac{\partial l_{n s}^{1}}{\partial w_{s}^{1}} \frac{\partial w_{s}^{1}}{\partial g_{n}} .
$$

Therefore, an increase in the public input good influences the level of outsourcing via two channels: first, a direct effect (measured by equation (9) with $w_{s}^{1}$ held constant) and, second, an indirect effect via $w_{s}^{1}$. To be able to interpret the relationship between $g_{n}$ and $l_{n s}^{1}$ in terms of whether the public input good is complementary with, or substitutable for, outsourcing in the North, we add the assumption that the direct effect of the northern public input good on the level of outsourcing always dominates the indirect effect via the southern wage rate. This assumption is based on the idea that the amount of southern labor used by northern firms is small relative to the aggregate number of work hours supplied by the low-skilled in the South, suggesting that the northern policy variables may have a 
relatively modest effect on the wage rate facing the low-skilled in the South. This assumption is summarized as follows;

A2. $\operatorname{sign} \frac{d l_{n s}^{1}}{d g_{n}}=\operatorname{sign} \frac{\partial l_{n s}^{1}}{\partial g_{n}}$.

Let $F_{n, g}=a_{n}^{1^{\prime}}\left(g_{n}\right) l_{n}^{1} F_{n, 1}+a_{n}^{2^{\prime}}\left(g_{n}\right) l_{n}^{2} F_{n, 2}>0$ denote the marginal product of the public input good. To be able to interpret the policy rule for public provision, we consider a situation where the marginal product of the public input good is diminishing in the sense that $d F_{n, g} / d g_{n}<0$. The first order condition for the public input good can now be written as

$$
\gamma_{n}\left[F_{n, g}-1\right]=-\lambda_{n} \hat{u}_{n, z}^{2} l_{n}^{1} \frac{\partial \phi_{n}}{\partial g_{n}}-\gamma_{n}\left[\Lambda_{n} \frac{d l_{n s}^{1}}{d g_{n}}-\frac{\partial w_{s}^{1}}{\partial g_{n}} l_{n s}^{1}\right]
$$

Equation (20) is written such as to emphasize the incentives to deviate from the first best policy rule given by $F_{n, g}-1=0$. The first term on the right hand side appears because a change in the public input good directly affects the wage ratio and, therefore, the incentive for the high-ability type to mimic the low-ability type. ${ }^{11}$ The interpretation is that the national government has an incentive to overprovide the public input good relative to the first best policy rule, if an increase in the public input good leads to a more equal wage distribution, i.e. if $\partial \phi_{n} / \partial g_{n}>0$. The analogous argument for underprovision follows if an increase in the public input good leads to more wage-inequality, so $\partial \phi_{n} / \partial g_{n}<0$.

The second term on the right hand side (the expression within square brackets) is due to the appearance of outsourcing, and represents the direct effect that outsourcing has on the policy rule for the public input good. It will, therefore, be referred to as the direct effect of outsourcing. ${ }^{12}$ According to equation (20), this effect comprises two parts. The first arises via the self-selection constraint, as an increase in the public input good affects the size of outsourced labor and, therefore, the wage ratio. As such, it also influences the

A similar effect is derived by Matsumoto (2001).

Note that outsourcing may also have indirect effects on the other terms in equation (20), i.e. the terms that would comprise the policy rule in the absence of outsourcing. 
incentives for the high-ability type of becoming a mimicker. The second is a budget effect due to that outsourcing gives rise to a discrepancy between production and income: an increase in the public input good in the North directly affects the wage rate paid to lowability labor in the South and, therefore, the payment for foreign labor services by northern firms. The optimal policy response to outsourcing by the northern government can then be summarized as in Proposition 1;

Proposition 1. Under assumption A2, and if the public input good is substitutable for (complementary with) outsourcing, then the direct effect of outsourcing from the North to the South contributes to increase (decrease) the optimal provision of the public input good in the North.

The intuition behind Proposition 1 is as follows. If the public input good is substitutable for outsourcing, then the government in the North may reduce the level of outsourcing by increasing the provision of the public input good. This policy response leads to less outsourcing, which contributes to a more equal domestic wage distribution and, therefore, a relaxation of the self-selection constraint. ${ }^{13}$ It also contributes to reduce the southern wage rate for low-ability labor and, therefore, the payments for foreign labor services by domestic firms. If the public input good is complementary with outsourcing, on the other hand, the opposite policy response will follow: the government in the North may, in this case, reduce the level of outsourcing as well as the payments for foreign labor services by lowering the provision of the public input good.

\subsection{Public Input Provision in the South}

The policy problem in the South is written such that the government chooses $l_{s}^{1}, c_{s}^{1}, l_{s}^{2}, c_{s}^{2}$ and $g_{s}$ to maximize the Lagrangean

$$
L_{s}=W_{s}+\lambda_{s}\left[u_{s}^{2}-\hat{u}_{s}^{2}\right]+\gamma_{s}\left[F_{s}-c_{s}^{1}-c_{s}^{2}-g_{s}+w_{s}^{1} l_{n s}^{1}\right]
$$

13 Aronsson and Koskela (2009b) derive a similar incentive for public input provision in an economy with equilibrium unemployment. 
subject to equations (9), (13) and (17). The government in the South treats the decisionvariables of the northern government as exogenous. The first order conditions for $l_{s}^{1}, c_{s}^{1}, l_{s}^{2}$ and $c_{s}^{2}$ are presented in the Appendix.

As we did for the North, we begin the analysis by deriving the welfare effect for the South of a small increase in the amount of outsourced labor, $l_{n s}^{1}$. We have

$$
\Lambda_{s}=\frac{\partial L_{s} / \partial l_{n s}^{1}}{\gamma_{s}}=\frac{\lambda_{s}}{\gamma_{s}} \hat{u}_{s, z}^{2} l_{s}^{1} \frac{\partial \phi_{s}}{\partial l_{n s}^{1}}>0
$$

Therefore, as increased outsourcing from the North to the South leads to less wageinequality in the South, it also contributes to increase southern welfare.

Let $F_{s, g}>0$ denote the marginal product of the public input good in the southern economy. By analogy to the analysis carried out above, we consider a case where this marginal product decreases in $g_{s}$. The first order condition for public input provision can now be written as

$$
\gamma_{s}\left[F_{s, g}-1\right]=-\lambda_{s} \hat{u}_{s, z}^{2} l_{s}^{1} \frac{\partial \phi_{s}}{\partial g_{s}}-\gamma_{s}\left[\Lambda_{s} \frac{\partial l_{n s}^{1}}{\partial w_{s}^{1}}+l_{n s}^{1}\right] \frac{\partial w_{s}^{1}}{\partial g_{s}}
$$

In a way similar to equation (20), we have written the first order condition in a way that characterizes the incentives to deviate from the first best policy rule. The first term on the right hand side of equation (22) is analogous to, and has the same interpretation as, the corresponding effect for the North described above.

The second term on the right hand side represents the direct effect of outsourcing on the policy rule for the public input good. This effect differs from its counterpart for the North. The reason is that the government in the South can only affect the level of outsourcing indirectly via the wage rate paid to low-ability labor. Furthermore, the term within the square bracket cannot be signed unambiguously, as a decrease in $w_{s}^{1}$ contributes to more outsourcing (which leads to higher welfare for the South via a relaxation of the 
self-selection constraint) as well as to lower factor income from abroad (which leads to lower welfare in the South).

We have derived the following result;

Proposition 2. Suppose that assumption A1 is fulfilled, so $\partial w_{s}^{1} / \partial g_{s}>0$.

(i) If $\Lambda_{s}\left(\partial l_{n s}^{1} / \partial w_{s}^{1}\right)+l_{n s}^{1}<0$, then the direct effect of outsourcing from the North to the South contributes to decrease the optimal provision of the public input good in the South.

(ii) If $\Lambda_{s}\left(\partial l_{n s}^{1} / \partial w_{s}^{1}\right)+l_{n s}^{1}>0$, then the direct effect of outsourcing from the North to the South contributes to increase the optimal provision of the public input good in the South.

The first part of Proposition 2 captures the case where the size of outsourced labor is small enough to imply that the budget effect is always dominated by the redistribution effect that outsourcing gives rise to. In this case, there is an incentive for the government in the South to provide a smaller public input good than it would otherwise have done. The intuition is that a lower public input good leads to more outsourcing from the North to the South which, in turn, contributes to relax the self-selection constraint facing the southern government. The second part of Proposition 2 captures the case where the budget effect is large enough to dominate: the government in the South then responds to outsourcing by increasing the provision of the public input good, as this leads to a greater budgetary gain in terms of income from abroad.

\section{Policy Cooperation}

Since the policy implemented by either country affects the well-being of the residents in the other country as well, the noncooperative equilibrium is not efficient from the perspective of society as a whole. Therefore, policy cooperation (if designed appropriately) will lead to higher welfare. We consider policy reforms designed to target the provision of the public input good, where the noncooperative Nash equilibrium is treated as the initial, prereform, equilibrium. 
Suppose that policy cooperation is governed by a Utilitarian objective

$$
W=W_{n}+W_{s}
$$

in which we give equal weight to the national welfare functions. By recalling that the noncooperative Nash equilibrium means that each national government has made an optimal policy choice conditional on the policies chosen by the other country, one can derive the following global welfare effect of a small increase in the provision of the public input good by each national government;

$$
\begin{aligned}
& \frac{\partial W}{\partial g_{n}}=\frac{\partial W_{s}}{\partial g_{n}}=\gamma_{s}\left[\Lambda_{s} \frac{d l_{n s}^{1}}{d g_{n}}+\frac{\partial w_{s}^{1}}{\partial g_{n}} l_{n s}^{1}\right] \\
& \frac{\partial W}{\partial g_{s}}=\frac{\partial W_{n}}{\partial g_{s}}=\gamma_{n}\left[\Lambda_{n} \frac{\partial l_{n s}^{1}}{\partial w_{s}^{1}}-l_{n s}^{1}\right] \frac{\partial w_{s}^{1}}{\partial g_{s}} .
\end{aligned}
$$

In addition, note that (by the Envelope Theorem)

$$
\frac{\partial W}{\partial c_{j}^{i}}=0 \text { for } i=1,2 \text {, and } j=n, s,
$$

in the noncooperative Nash equilibrium, as private consumption does not give rise to international externalities. Therefore, any change in private consumption induced by a change in the public input good has no first order welfare effect in the initial equilibrium. We have derived the following result;

Proposition 3. (i) Under assumption A2, and if the public input good is substitutable for (complementary with) outsourcing in the North, it follows that decreased (increased) public input provision in the North leads to higher welfare in the South.

(ii) Under assumption A1, and if $\Lambda_{n}\left(\partial l_{n s}^{1} / \partial w_{s}^{1}\right)-l_{n s}^{1}>0(<0)$, it follows that increased (decreased) public input provision in the South leads to higher welfare in the North.

Proposition 3 shows the conditions under which a small increase or decrease in the provision of the public input good by each national government leads to higher global welfare and, in this sense, whether each national government underprovides or 
overprovides the public input good from the perspective of society as a whole. The first part means that the North overprovides the public input good in a noncooperative equilibrium, if the public input good is substitutable for outsourcing. ${ }^{14}$ However, if the public input good is complementary with outsourcing, we obtain the opposite result; namely, that the North underprovides the public input good in the noncooperative equilibrium. This situation may arise if the degree of complementarity between the two types of domestic labor in the northern economy is relatively strong.

The second part of Proposition 3 relates the public input provision by the southern government to the size of outsourced labor, $l_{n s}^{1}$. If the size of outsourced labor is small enough to imply that the budget cost for the North of an increase in the wage rate paid to southern low-ability labor is small, so that the gain of reduced outsourcing for the North dominates the loss in terms of income payments to foreign residents, then the North would gain if the government in the South increases its public input provision. In this case, therefore, the South underprovides the public input good in the noncooperative equilibrium. The intuition is that increased public input provision in the South leads to an increase in the wage rate paid to low-ability labor in the South (according to assumption A1) and, therefore, to reduced outsourcing from the North to the South. This is welfare improving for the North as it contributes to reduced wage-inequality in the northern economy. However, if the size of outsourced labor is large enough, we may have the opposite result; namely, that the South overprovides the public input good in a noncooperative equilibrium. The reason is that the budgetary cost to the northern government of an increase in $w_{s}^{1}$ in this case may dominate the distributional gain of reduced outsourcing. As a consequence, the northern government would benefit from a decline in $w_{s}^{1}$, which can be accomplished by decreased public input provision in the South.

\section{Summary and Discussion}

14 Egger and Falkinger (2006) also derive an "overprovision result”, although by focusing on the relationship between outsourcing and international firm mobility. 
This paper concerns the role of public input provision as a means of redistribution in the presence of outsourcing by using a model-economy comprising two countries, North and South, where firms in the North may outsource part of their low-skilled labor intensive production to the South. We examine two interrelated issues: the incentives for each national government to adjust its provision of public input goods in response to outsourcing in the absence of any policy cooperation, and whether international outsourcing justifies policy cooperation with respect to the provision of public input goods.

For the North, the results show that if the public input good is substitutable for outsourcing in the sense that the marginal product of outsourced labor decreases with the provision of the public input good, then outsourcing of low-skilled labor intensive production from the North to the South contributes to increase the optimal provision of the public input good. The opposite policy incentive arises if the public input good is complementary with outsourcing; let be that this situation seems to be less realistic. For the South, the optimal policy response serves to balance two counteracting effects; a direct effect of outsourcing on the domestic wage distribution and a budget effect as residents of the South receive income paid by northern firms. If the direct welfare effect of outsourcing via the wage distribution dominates the budget effect - which happens if the level of outsourced labor is sufficiently small - the government in the South will respond to outsourcing by decreasing its provision of the public input good. On the other hand, if the budget effect dominates (which it may do if the level of outsourced labor is large enough), we obtain the opposite result that the South responds to outsourcing by increased public provision.

Policy cooperation is assumed to be governed by a Utilitarian utility sum over the countries. We examine whether a small increase or decrease in the provision of the public input good by each national government leads to higher global welfare and, in this sense, whether each national government underprovides or overprovides the public input good from the perspective of society as a whole. The results show that the North overprovides the public input good in a noncooperative equilibrium, if the public input good is substitutable for outsourcing. This means that a small decrease in the public provision by the northern government leads to higher welfare in the South. The opposite result follows 
if the northern public input good is complementary with outsourced labor. By analogy to the results discussed above, whether the government in the South overprovides or underprovides the public input good from the perspective of society as a whole in the noncooperative equilibrium depends on the level of outsourcing. If the size of outsourced labor is small enough, it follows that the North would gain if the southern government increases the provision of the public input good. In this case, therefore, the South underprovides the public input good in the noncooperative equilibrium.

Future research might take several new directions. For instance, we have completely neglected the role of non-competitive wage formation. If the North is thought of as a European economy, it would clearly be relevant to allow trade-unions to affect wage formation for low-skilled labor and, as a consequence, allow for equilibrium unemployment among the low-skilled in the North. ${ }^{15}$ As trade-unions may attempt to push up the wage rate above the competitive level, there will most likely be an even stronger incentive for firms in the North to outsource production capacity to the South. In addition, it is not necessarily the case that low-skilled labor intensive jobs outsourced from a developed economy are perceived as low-skilled labor intensive jobs also in a developing economy. To be more specific, differences in skill-distributions may imply that outsourcing contributes to more wage-inequality both in the North and South. The incentives facing the southern government will, in this case, differ from those described in this paper. We leave these and other extensions for future research.

\section{Appendix}

\section{The North}

The first order conditions for $l_{n}^{1}, c_{n}^{1}, l_{n}^{2}$ and $c_{n}^{2}$ can be written as

$$
-\frac{\partial W_{n}}{\partial u_{n}^{1}} u_{n, z}^{1}+\lambda_{n} \hat{u}_{n, z}^{2}\left[\phi_{n}+l_{n}^{1} \frac{\partial \phi_{n}}{\partial l_{n}^{1}}\right]+\gamma_{n}\left[w_{n}^{1}-\frac{\partial w_{s}^{1}}{\partial l_{n}^{1}} l_{n s}^{1}+\Lambda_{n} \frac{d l_{n s}^{1}}{d l_{n}^{1}}\right]=0
$$

15 Such an extension may also include product market imperfections. There is a growing literature dealing with relationships between non-competitive wage formation, product market imperfections, globalization and outsourcing, although so far with a focus on issues other than redistribution via public input provision. See, e.g., Naylor $(1998,1999)$ and Lommerud et al. (2003). 


$$
\begin{aligned}
& \frac{\partial W_{n}}{\partial u_{n}^{1}} u_{n, c}^{1}-\lambda_{n} \hat{u}_{n, c}^{2}-\gamma_{n}=0 \\
& -\left[\frac{\partial W_{n}}{\partial u_{n}^{2}}+\lambda_{n}\right] u_{n, z}^{2}+\lambda_{n} \hat{u}_{n, z}^{2} l_{n}^{1} \frac{\partial \phi_{n}}{\partial l_{n}^{2}}+\gamma_{n}\left[w_{n}^{2}-\frac{\partial w_{s}^{1}}{\partial l_{n}^{2}} l_{n s}^{1}+\Lambda_{n} \frac{d l_{n s}^{1}}{d l_{n}^{2}}\right]=0 \\
& {\left[\frac{\partial W_{n}}{\partial u_{n}^{2}}+\lambda_{n}\right] u_{n, c}^{2}-\gamma_{n}=0 .}
\end{aligned}
$$

The South

The first order conditions for $l_{s}^{1}, c_{s}^{1}, l_{s}^{2}$ and $c_{s}^{2}$ become

$$
\begin{aligned}
& -\frac{\partial W_{s}}{\partial u_{s}^{1}} u_{s, z}^{1}+\lambda_{s} \hat{u}_{s, z}^{2}\left[\phi_{s}+l_{s}^{1} \frac{\partial \phi_{s}}{\partial l_{s}^{1}}\right]+\gamma_{s}\left[w_{s}^{1}+\frac{\partial w_{s}^{1}}{\partial l_{s}^{1}} l_{n s}^{1}+\Delta_{s} \frac{\partial l_{n s}^{1}}{\partial w_{s}^{1}} \frac{\partial w_{s}^{1}}{\partial l_{s}^{1}}\right]=0 \\
& \frac{\partial W_{s}}{\partial u_{s}^{1}} u_{s, c}^{1}-\lambda_{s} \hat{u}_{s, c}^{2}-\gamma_{s}=0 \\
& -\left[\frac{\partial W_{s}}{\partial u_{s}^{2}}+\lambda_{s}\right] u_{s, z}^{2}+\lambda_{s} \hat{u}_{s, z}^{2} l_{s}^{1} \frac{\partial \phi_{s}}{\partial l_{s}^{2}}+\gamma_{s}\left[w_{s}^{2}+\frac{\partial w_{s}^{1}}{\partial l_{s}^{2}} l_{n s}^{1}+\Delta_{s} \frac{\partial l_{n s}^{1}}{\partial w_{s}^{1}} \frac{\partial w_{s}^{1}}{\partial l_{s}^{2}}\right]=0 \\
& {\left[\frac{\partial W_{s}}{\partial u_{s}^{2}}+\lambda_{s}\right] u_{s, c}^{2}-\gamma_{s}=0 .}
\end{aligned}
$$

\section{References}

Aronsson, T. and Koskela, E. (2009a) Outsourcing and Optimal Nonlinear Taxation: A Note. Economics Letters 102, 135-137.

Aronsson, T. and Koskela, E. (2009b) Optimal Redistributive Taxation and Provision of Public Input Goods in an Economy with Outsourcing and Unemployment, IZA Discussion Paper No. 4196, May, University of Bonn.

Aronsson, T. and Koskela, E. (2009c) Optimal Income Taxation, Outsourcing and Policy Cooperation in a Dynamic Economy. Umeå Economic Studies no 784.

Aronsson, T. and Wekhe, S. (2008) Public Goods, Unemployment and Policy Coordination. Regional Science and Urban Economics 38, 285-298.

Egger, H. and Egger, P. (2006) International Outsourcing and the Productivity of LowSkilled Labor in the EU. Economic Inquiry 44, 237-258. 
Egger, H. and Falkinger, J. (2006): The Role of Public Infrastructure and Subsidies for Firm Location and International Outsourcing. European Economic Review 50, 19932015.

Ethier, W.J. (2005) Globalization, Globalisation: Trade, Technology and Wages. International Review of Economics and Finance 14, 237-258.

Feehan, J.P. (1989) Pareto-Efficiency with Three Varieties of Public Input. Public Finance 44, 237-248.

Feehan, J.P and Matsumoto, M. (2000) Productivity-enhancing Public Investment and Benefit Taxation: the Case of Factor-augmenting Public Inputs. Canadian Journal of Economics 33, 114-121.

Feenstra, R.C. and Hanson, G.H. (1999) The Impact of Outsourcing and High-Technology Capital on Wages. Quarterly Journal of Economics 114, 907-940.

Feenstra, R.C. and Hanson, G.H. (2003) Global Production Sharing and Rising Inequality: A Survey of Trade and Wages. In Choi, E. and Harrigan, J. (eds) Handbook of International Trade, Blackwell Publishing Ltd.

Geishecker, I. and Görg, H. (2008) Winners and Losers: A Micro-Level Analysis of International Outsourcing and Wages. Canadian Journal of Economics 41, 243-270.

Goldberg, P.K. and Pavcnik, N. (2007) Distributional Effects if Globaslization in Developing Countries. Journal of Economic Literature XLV (March 2007), 39-82.

Haskel, J. and Slaughter, M.J. (2001) Trade, Technology and U.K. Wage Inequality, Economic Journal 111, 163-187.

Hijzen, A. (2007) International Outsourcing, Technological Change, and Wage Inequality. Review of International Economics 15, 188-205.

Hijzen, A. Görg, H. and Hine, R.C. (2005) International Outsourcing and the Skill Structure of Labor Demand in the United Kingdom. Economic Journal 115, 860-878.

Hillman, A.L. (1978) Symmetries and Asymmetries between Public Input and Public Good Equilibria. Public Finance 33, 267-279.

Hsieh, C-T. and Woo, K.T. (2005) The Impact of Outsourcing to China on Hong Kong's Labor Market. American Economic Review 95, 1673-1687.

Keuschnigg, C. and Ribi, E. (2009) Outsourcing, Unemployment and Welfare. Journal of International Economics 78, 168-176.

Koskela, E. and Stenbacka, R. (in press) Equilibrium Unemployment with Outsourcing and Wage Solidarity under Labor Market Imperfections. European Economic Review.

Lommerud, K.E., Meland, F. and Sorgand, I. (2003) Unionized Oligopoly, Trade Liberalization and Location Choice. Economic Journal 113, 782-800.

Martin, P. and Rogers, C.A. (1995) Industrial Location and Public Infrastructure.Journal of International Economics 39, 335-351. 
Matsumoto, M. (1998): A Note on Tax Competition and Public Input Provision. Regionla Scuience and Urban Economics 28, 465-473.

Matsumoto, M. (2001) Public Input Provision in an Optimal Income Tax Model. FinanzArchiv 58, 12-30.

Matsumoto, M. (2004) The Mix of Public Inputs under Tax Competition. Journal of Urban Economics 56, 389-393.

McMillan, J. (1979) A Note of the Economics of Public Intermediate Goods. Public Finance 34, 293-299.

Munch, J.R. and Skaksen, J.R. (2009) Specialization, Outsourcing and Wages. Review of World Economics 145, 57-73.

Naylor, R. (1998) International Trade and Economic Integration When Labor Markets are Generally Unionized. European Economic Review 42, 1251-1267.

Naylor, R, (1999) Union Wage Strategies and International Trade. Economic Journal 109, 102-125.

Riley, R. and Young, G. (2007) Skill Heterogeneity and Equilibrium Unemployment, Oxford Economic Papers 59, 702-725.

Stern, N.H. (1982) Optimum Taxation with Errors in Administration. Journal of Public Economics 17, 181-211.

Stiglitz, J. E. (1982) Self-Selection and Pareto Efficient Taxation. Journal of Public Economics 17, 213-240.

Wilson, J.D. (1999) Theories on Tax Competition. National Tax Journal 52, 269-304. 